\title{
MRC2 wt Allele
}

National Cancer Institute

\section{Source}

National Cancer Institute. MRC2 wt Allele. NCI Thesaurus. Code C104646.

Human MRC2 wild-type allele is located in the vicinity of $17 q 23.2$ and is approximately 66 $\mathrm{kb}$ in length. This allele, which encodes C-type mannose receptor 2 , plays a role in extracellular matrix remodeling and may play a role in tumorigenesis and metastasis. 